ESSAY ROUNDTABLE

\title{
CHRISTIANITY AND HUMAN FLOURISHING: THE ROLES OF LAW AND POLITICS
}

\section{DAVID N. HEMPTON}

Dean, John Lord O’Brian Professor of Divinity, and McDonald Family Professor of Evangelical Theological Studies, Harvard Divinity School

KEYWORDS: Christianity, law, human flourishing, violence, peacebuilding, Enlightenment, religious freedom, justice

This essay was presented as a $2016 \mathrm{McD}$ onald Distinguished Scholar Lecture at the Center for the Study of Law and Religion, Emory University.

\section{INTRODUCTION: THREE THREATS TO HUMAN FLOURISHING}

If I were to ask of any group to identify the three most dangerous threats to human flourishing in the twenty-first century, I am sure that I would get a wide variety of answers. For many of these threats-from climate change and looming ecological disasters to the structural inequalities of the global economic system, and from the disturbing prevalence of both nuclear and the new autonomous weapons to the continuing possibility of interstate warfare-I have no particular expertise to draw on beyond that of any concerned citizen in the world's most powerful democracy. In order to address the topic of Christianity and human flourishing, I speak from my own perspective as a Western Christian who grew up in a deeply divided and violent society in Northern Ireland during the Troubles and who now finds himself dean of one of the world's most religiously diverse divinity schools. From those perspectives, I identify what I see as the three most dangerous threats to human flourishing.

First, although I basically agree with many of my colleague Steven Pinker's conclusions in his book Our Better Angels that, however counterintuitive it might seem, the world is less violent now than at any stage in its history, nevertheless I regard violence, especially intrastate or civil wars, which are often internationalized, as primary threats to human flourishing. ${ }^{\mathrm{I}}$ My own experience in Belfast; the unspeakable suffering in Afghanistan, Iraq, Syria, and South Sudan; and the resultant, heartbreaking refugee crises, make this threat abundantly clear. Although Pinker's treatment of religion is perhaps the least satisfactory part of his book, ${ }^{2}$ one can easily see why many cognitive scientists and behavioral and social psychologists in the Western academy see religion

I See generally Steven Pinker, The Better Angels of Our Nature: Why Violence Has Declined (New York: Penguin, 2OII).

2 Pinker's articulation of the violence of some parts of the Hebrew Bible and the history of Christendom is appropriate, but less convincing is his assessment of the role of religion in conflicts such as the Thirty Years' War in Europe and the Troubles in Northern Ireland, or in paying at least some tribute to the role of religion in peacebuilding in many different conflicts. 
itself as a, or even the, primary threat to human flourishing. This is an argument that needs to be taken seriously.

Second, I see a major threat to human flourishing in the emergence of global fundamentalist movements in many of the world's religious traditions, often intersecting with exclusivist and angry political movements to produce a deadly mixture of political and religious intolerance. This threat is most acute in places that have suffered from the legacies of Euro-American colonialism, religiously infused ethno-nationalism, and deeply sectarian interpretations of sacred texts. This problem may get worse, if, as the recent Pew survey on global religious trends predicts, the West becomes more religiously unaffiliated (probably more secular), while the rest of the world, especially the global South and East, becomes more competitively religious primarily as a result of demographic trends. ${ }^{3}$ The growing religious illiteracy of the West, especially the well-documented case of the United States, is itself a dangerous reality.

Finally, a third threat to human flourishing, more difficult to diagnose than the first two, emanates from the long-term dynamics of what I might call the Enlightenment project in the Western academy. Scientific rationalism, functionalist utilitarianism, technological innovation, and the decline of the humanities has resulted in a separation of head and heart and a diminution of empathy, emotional intelligence, and vigorous educational debates about questions of meaning or the well-lived life. I am the dean of a divinity school in an elite institution celebrating its two hundredth birthday. One interpretation of our school's founding, as with many other university divinity schools, was to remove theological and religious studies from the main preoccupations of the modern research university so that those universities could get on with the real business of generating new knowledge and producing scientific and technological improvement. In the last several years, our colleges and universities have been roiled by complex structural and moral issues in our society: from race and "Black Lives Matter" to shocking statistics about the prevalence of sexual assault and harassment on college campuses, and from deep concern about growing economic inequality and the use of university endowments to the depressing state of our political discourse. It is not at all clear, however, that the curriculum of the modern university is well placed to deal with issues relating to ethics, meaning, and purpose.

\section{WHAT CONTRIBUTION CAN CHRISTIANITY MAKE TO ADDRESS THESE THREATS TO HUMAN FLOURISHING?}

I begin with a historical case study. I am not a lawyer and have no legal training, but for a couple of years in my career I worked intensively on legal history for a book I was writing. In the course of my research, I came across a letter written in 1747 from the justices of the peace in the West of England to the Anglican bishop of Exeter. In the early modern period most European states had established churches with serious legal penalties against those who dissented from those churches -in other words churches were part of the theory and practice of governing and were regarded as instrumental in securing political loyalty, social stability, and communal harmony. Dissent from established churches was either tolerated within very strict boundaries, as in England; subject to serious penal codes, as in Ireland; or ruthlessly suppressed, as in various parts of continental Europe. Such repression often led to enforced migrations from intolerant

3 Pew Research Center, “The Future of World Religions: Population Growth Projections, 2010-2050," April 2015, http://www.pewforum.org/2OI 5/O4/O2/religious-projections-2010-2050/. 
confessional states, as with the notorious case of the Salzburg Protestants, many of whom fetched up in the North American colony of Georgia in the early eighteenth century. ${ }_{4}^{4}$ This context of confessional states with legally privileged established churches helps explain the letter from the justices of the peace in the West Country of England in the late I740s. This is what they wrote:

A set of people who stile themselves Methodists have infus'd their enthusiastick notions into the minds of vast numbers of the meaner sort of people in the Western part of this County; they are strenuously endeavouring to propagate themselves all over it: several have assembled frequently within this fortnight in the parish of Saint Ewe in which we live; and the preacher they are so very fond of, is not better than a mean illiterate Tinner, and what is more surprising, but a boy nineteen years old. Doubtless your Lordship has heard much of these poor deluded creatures ... who for the most part are ignorant men, and have been notoriously wicked, but now under pretence of being both reform'd and inspired, they, and even women of the same stamp are adored preachers: it is sufficient to say that many poor wretches have been drove to despair thro' their means, and multitudes of his Majesties subjects have been made useless in every station of life, by being persuaded, that unless they are Drones and Cowards they cannot be saved. As we are in the Commission of the Peace, we have endeavour'd to convince them of their errors by reason: which not having the least effect, we told them that we must put the Laws in effect against them. ${ }^{5}$

What the justices of the peace were protesting, essentially, was the fact that ordinary men and women, without ecclesiastical authorization or legally obtained licenses, were propagating religious opinions outside the discipline and control of the established church and hence posed a real threat to political control and social stability.

Fast-forwarding half a century, this new religious movement, the Methodists, played a major role (and I mean major role) in expanding religious toleration and freedom in England, advocating for the separation of church and state and religious equality in the United States, and in petitioning against the end of the Atlantic slave trade in 1807 and the abolition of slavery within British colonial dominions in 1833.6 The message here is that a once disparaged religious movement, over time, displayed the capacity to advocate for and legally help secure three of the most important legal and humanitarian transformations in the history of the modern West: the separation of church and state; the rise of religious toleration, and later, religious equality; and the end of state-sponsored slavery.

At the risk of eulogizing or romanticizing this populist evangelical religious movement, it is also possible to argue that popular evangelicalism of all stripes also made a significant contribution to many other humanitarian and emancipatory causes in the eighteenth and nineteenth centuries from protecting animals from cruelty to rolling back enforced ecclesiastical taxation, and from pioneering working-class education through the ubiquitous Sunday Schools to prizing open the many inherited privileges of elite supported established churches. My gloss on this would be to suggest that Christian movements have always been at their best when their agendas are about expanding human freedom, protecting the vulnerable, and fighting against injustice. There was, of course, a

4 This remarkable story is told by W. R. Ward, The Protestant Evangelical Awakening (Cambridge: Cambridge University Press, 1992), 103-7.

5 West Austell JPs to G. Lavington, Bishop of Exeter, 23 May 1747, Lambeth Palace Library Manuscripts, Secker Papers, 8 (Methodists), folios 4-5. For a fuller treatment, see David Hempton, The Religion of the People: Methodism and Popular Religion c. I750-I900 (London: Routledge, I996), I45-6I.

6 See David Hempton, "Popular Evangelicalism and the Shaping of British Moral Sensibilities, I770-1830," in British Abolitionism and the Question of Moral Progress in History, ed. Donald A. Yerxa (Columbia: University of South Carolina Press, 20I2), 58-80. 
darker side to these movements: a nasty sectarian anti-Catholicism, and what I would call an emboldened moral majoritarianism in trying to enforce Sabbatarianism, temperance, and the colonial export of Christianity, commerce, and civilization, which has produced such a bitter legacy in the world. When religious movements move from a freedom and justice agenda to an exclusivist sectarian or moral coercion agenda, what Charles Dickens in Hard Times called trying to make people religious by main force, 7 bad things almost always follow. When Christianity, or indeed any religion, so infuses political culture as to build a harmony of interests against other competing interests - for example the fusion of Paisleyite fundamentalism and Unionist politics in Northern Ireland, or the culture wars and their Republican and Democratic party formulations in the United States-politics often become a zero-sum game in which one side can only prosper at the expense of the other. Zero-sum games take the elasticity and flexibility out of political culture and inexorably make political culture angrier, more intolerant, and more destructive of human flourishing. In a recent New York Times editorial, David Brooks called this the "antipolitics tendency." Quoting Bernard Crick's dictum that "Politics is a way of ruling divided societies without undue violence," he wrote that "antipolitics people don't accept politics as a limited activity. They make soaring promises and raise ridiculous expectations. When those expectations are not met, voters grow cynical and, disgusted, and turn even further in the direction of antipolitics." 8 This is not new wisdom, but is essentially the same advice given by the prophet Jeremiah to the exiled children of Israel in Babylon, "Seek the welfare of the city where I have sent you into exile, and pray to the Lord on its behalf, for in its welfare you will find your welfare ... for I know the plans I have for you, says the Lord, plans for welfare and not for evil, to give you a future and a hope." 9 Discovering welfare and hope in the midst of human exile and conflict is perhaps one of the best definitions of human flourishing we can come up with.

\section{RELIGION, VIOLENCE, AND PEACEBUILDING}

It was partly acknowledging the historical reality that religious movements of all kinds can have immensely positive impacts on society, along with my opposite experience of religion as a contributor to violence and conflict when I was growing up and studying in Belfast during the worst of the Troubles, that we started the Religions and the Practice of Peace initiative at Harvard two years ago. The aim was to bring the intellectual resources of Harvard Divinity School, in association with other schools at Harvard, to bear on the great issues of our time with respect to religion, violence, and peacebuilding.

What we are trying to do is closely aligned with the views expressed in Rabbi Jonathan Sacks's recent book, Not in God's Name: Confronting Religious Violence. ${ }^{\text {}}{ }^{\circ}$ This book is designed to refute three common arguments made about the relationship between religion and violence and war:

I. Religion is the major source of violence in our world and needs to be marginalized or eliminated.

2. Although religion can be used by manipulative leaders to motivate people to wage wars out of a desire for sectarian dominance or purity, religion itself basically teaches us to love and

7 Charles Dickens, Hard Times (London, I 854), chapter 5, "The Key Note."

8 David Brooks, "The Governing Cancer of Our Times," New York Times, February 26, 2016.

9 Jeremiah 29:7-I I (Revised Standard Version).

Io Jonathan Sacks, Not in God's Name: Confronting Religious Violence (New York: Schocken Books, 20I 5 ). 
forgive, not fight and hate. (This view actually piles the blame on to political leaders and gives religion a pass.)

3. The idea that "our" religion is peaceful but "theirs" is intolerant and violent. (Whatever the religion and culture, history seems to show that under conditions in which normal constraints are removed humans have the same capacity for cruelty and barbarity.)

Sacks disagrees with all of these views. His view is that religion shows no signs of diminishing in importance in our world, and contributes more than we like to think to what he calls "altruistic evil." His suggestion is that we must all do hard theological work to diminish the influence of the worst aspects of religious extremism and promote the best of what religion has to offer the world. In his words, "We must raise a generation of young Jews, Christians, Muslims, and others to know that it is not piety but sacrilege to kill in the name of the God of life, hate in the name of the God of love, wage war in the name of the God of peace, and practice cruelty in the name of the God of compassion.” ${ }_{\text {II }}$

In the two years of the existence of the Religions and the Practice of Peace Initiative, we have partnered with many other American universities, state and voluntary organizations, and on-the-ground practitioners to promote peacebuilding efforts. Along the way we have learned three things in particular:

I. Religious peacebuilding needs to be brought into close conversation with new expertise on global development and ecological sustainability. We also need to support efforts by international lawyers and human rights activists to make wars of aggression into war crimes, if we are really serious about reducing the incidence of violence and warfare.

2. In the developing arts of peacebuilding, we need to find more space for the creative work of women (wars are primarily male events) and also what John Lederach calls the cultivation of "the moral imagination." ${ } 2$

3. Religious traditions, of all kinds, have within them deep practices of spirituality and conflict mediation. We need to drill deeply into those traditions and construct a new narrative and a new pedagogy about the role of religion in the twenty-first-century world. Using the constructive power of religious traditions and universities (both of which are global institutions) to get behind the cumulative international treaties and declarations against the illegal use of force is something worth advocating for. War and violence are the absolute opposites of human flourishing, and they always produce the nadir of human behavior, yet sixty years after the Nuremburg war trials and the Universal Declaration of Human Rights, we still struggle to build international commitment to human rights, international law, and the illegal use of force. Despite our slow progress, however, there is some evidence to suggest that historical efforts to use law to limit war and human rights abuses have made a difference to the use of force in the twentieth century. ${ }^{\mathrm{I}}$ Is it possible that new developments in the laws of war such as the Rome Statute of the International Criminal Court and the Kampala amendment will produce further gains in the twenty-first century?

I I Jonathan Sacks, "How to Defeat Religious Violence” Wall Street Journal, October 2, 2015.

I John Paul Lederach, The Moral Imagination: The Art and Soul of Building Peace (New York: Oxford University Press, 2005).

I3 This is the argument of Kathryn Sikkink, Federica D'Alessandra, and Aroop Mukarji, "Has International Law Diminished the Illegal Use of Force?, unpublished paper, Carr Center for Human Rights, Harvard University, 2016. 
In a book with the great title To Make the Earth Whole, Marc Gopin makes a case for the art of citizen diplomacy in an age of religious militancy. ${ }^{\mathrm{I}} 4$ Some of that diplomacy will be exercised by governments, state departments, and professionals. But, let us be honest, their record has not been entirely stellar, and Gopin urges all of us to be involved in building a global contract of peace and sustainability. Many "citizen diplomats" will be secular humanitarians, which is all to the good, but Gopin makes a special plea for those he calls "spiritual peacebuilders." He writes,

The best of the peacemakers recognize our common humanity and they harmonize this with spirituality, making them true heirs to the future. They are spiritual, but not coercive; they live with their eyes on the sacred ... They know how to weave peace and justice together without violence in a unique way that enters into the hearts of average people of faith. They have taken the best of religious inspiration and wedded it to nonviolence. They are trained in radical empathy, trained in visualizing the whole. ${ }^{15}$

There can be no better description of how spiritual and religious sensibilities, at their most compelling, bring special qualities to peacebuilding that social scientific methods and theories, however necessary they are, cannot achieve alone.

\section{CONCLUSION}

The English novelist George Eliot, a disenchanted evangelical Christian turned secular humanist wrote, "Religious ideas have the fate of melodies, which, once set afloat in the world are taken up by all sorts of instruments, some of them woefully coarse, feeble or out of tune, until people are in danger of crying out that the melody itself is detestable." ${ }^{6}$ We live in a world, indeed in a nation, where religious ideas have been taken up by out-of-tune instruments, and many in the West, especially under the age of thirty, now believe the melody itself is detestable. The time is urgent to think afresh about Christianity and human flourishing and how politics and law can help compose a more harmonious melody. The themes of that melody should be about campaigning for greater human freedom from prejudice and oppression; about building international resistance to wars of aggression and war crimes; about advocating for social justice and human dignity; about pressing for ecological sustainability; and about educating our students how to think about things bigger than themselves and their own material well-being. In sum, we need to make our earth whole. Humans flourish when human flourishing is top of the agenda, and they shrivel in the spaces occupied by war, violence, and ruthless self-interest. Blessed indeed are the peacemakers for they will be called the children of God.

I Marc Gopin, To Make the Earth Whole: The Art of Citizen Diplomacy in an Age of Religious Militancy (Lanham: Rowman \& Littlefield, 2009). See also Marc Gopin, Between Eden and Armageddon: The Future of World Religions, Violence, and Peacemaking (New York: Oxford University Press, 2000).

I5 Gopin, To Make the Earth Whole, 226.

I6 George Eliot, “Janet's Repentance," in Scenes of Clerical Life (London: Blackwood and Sons, I 858). 